\title{
Physical mapping of ribosomal RNA genes in the genus Artemi- sia L. (Asteraceae)
}

\author{
Hoshi $^{1 *}$ Yoshikazu, Hideyuki Matoba ${ }^{1}$ and Katsuhiko Kondo ${ }^{2}$ \\ ${ }^{1}$ Department of Plant Science, Kyushu Tokai University, kawayo, Minamiaso-mura, Kumamoto, 869-1404, Japan; \\ ${ }^{2}$ Laboratory of Plant Chromosome and Gene Stock, Graduate of Science, Hiroshima University, Higashi-Hiro- \\ shima 739-8526, Japan.
}

\begin{abstract}
The fluorescence in situ hybridization (FISH) using $5 \mathrm{~S}$ and $18 \mathrm{~S}$ rDNA probes was applied to four species of the genus Artemisia. In all four Artemisia species, 5S and 18S rDNA were located in the terminal position. Moreover, all 18S rDNA sites were the same number and collocated with $5 \mathrm{~S}$ rDNA. The collocation of the $5 \mathrm{~S}$ and $18 \mathrm{~S}$ rDNA might be a common feature of chromosome evolution in the genus Artemisia. In section Dracunculus have eight and nine rDNA sites while section Artemisia has four rDNA sites. Despite the polyploidy had been observed, the number of rDNA sites were relatively constant within the section Dracunculus and Artemisia respectively.
\end{abstract}

Key words: Artemisia, Dracunculus, FISH, polyploidization, rDNA.

\section{INTRODUCTION}

The genus Artemisia L. (Asteraceae) is the largest genus in the tribe Anthemideae (Asteraceae), and is consisted of more than 200 to 500 species, according to various authors (MCARTHUR 1978; MABberley 1990; Ling 1991a;b; BrEMER and Humphries 1993; VAlLÉS and SilJAK-YAKoVLEV 1997; Torrell et al. 1999; Torrell and VALLÉs 2001). This genus is widely distributed in the Northern Hemisphere, but is rather rare in the Southern Hemisphere (MCARTHUR and SANDERSON 1999; Torrell and Vallés 2001; KreitsCHITZ and VAllÉs 2003). Many chromosome numbers have been reported in the genus (MATSUURA and Suto 1935; Sakai 1935; Shimotomai 1946; Suzuka 1950; 1952; Masumori 1961; ARano 1962; 1964; Kawatani and Ohno 1964; Sharma and Sarkar 1968; Bolkohovskikh et al. 1969; Rousi 1969; BaKshi and Kaul 1984; MalaKHOVA 1990; McArthur and SANDERSON 1999; Hoshr et al. 2003). The most common basic chromosome number of the genus is $\mathrm{x}=9$, with ploidy levels up to dodecaploid (Sнiмотомai 1946; Suzuka 1952; Kawatani and Ohno 1964; MalaKHOVA 1990). In the genus Artemisia, polyploidy has played a major role in the karyological evolu-

\footnotetext{
* Corresponding author: phone and fax: +81-967-673919; e-mail: yhoshi@ktmail.ktokai-u.ac.jp
}

tion, however, their relationships and phylogeny are unclear (Arano 1962; Kawatani and Ohno 1964).

One of the most important roles in the evolution of higher plants is polyploidy, which have been estimated to be $70 \%$ of all angiosperm species (Stebbins 1971; Pamela and Douglas 2000). Thus, the study of chromosome numbers has provided essential information to examine phylogenetic relationships and speciation in higher plant. On the other hand, since the inter- and intraspecific similarity of chromosome conformation of this genus, it is difficult to clarify and justify the systematic relationships using karyotypes (MasUMORI 1961; ARANO 1962; 1963; 1965; 1970; Hoshi et al. 2003).

Fluorescence in situ hybridization (FISH) with rDNA is a useful marker for chromosome identification, which provides the phylogenetic information of closely related taxa (e.g., ANSARI et al. 1999; SingH 2001). In plant, FISH for ribosomal RNA genes have been widely used for karyotyping (Leitch and Heslop-Harrison 1993; Matoba et al. 2001; RAina et al. 2001; NAvrátiLovÁ et al. 2003), and for studying genome organization and chromosome evolution within many genera (Ali et al. 2000; ANAMthawat-JónSSON and BöDVARsótTIR 2001; Hasterok et al. 2001; Raina et al. 2001; RAN et al. 2001; SingH et al. 2001; Li and Zhang 2002). Recently, Torrell et al. $(2001 ; 2003)$ have reported the number of $5 \mathrm{~S}$ 
and18S rDNA loci in some species of Artemisia, but they did not refer on the Eurasian species.

In this study, we investigated the first time the $5 \mathrm{~S}$ and $18 \mathrm{~S}$ rDNA on the chromosomes in four species of the genus Artemisia. The aim of the present study was to investigate the number and loci of $5 \mathrm{~S}$ rDNA and $18 \mathrm{~S}$ rDNA using FISH, and consider the mechanism of chromosomal evolution in the genus Artemisia. Moreover, we investigated whether distribution of $5 \mathrm{~S}$ and $18 \mathrm{~S} \mathrm{rDNA}$ played a role in phylogenetic relationships among taxa in the genus Artemisia.

\section{MATERIALS AND METHODS}

Plant materials and chromosome preparation - Materials for the present study were collected in Japan and Russia, and were cultivated in the Department of Plant Science, Kyushu Tokai University (Table 1). The seedlings were pretreated with $2 \mathrm{mM}$ 8-hydroxyquinoline at room temperature for $3 \mathrm{~h}$ before they were fixed in ethanol-acetic acid $(3: 1)$ at $4^{\circ} \mathrm{C}$ for $24 \mathrm{~h}$. Chromosomal preparations were prepared by the modified method of Leitch and Heslop-Harrison (1993). Fixed seedlings were washed three times in distilled water and their root-tips were cut into $2-3 \mathrm{~mm}$ long. Ten to thirty root-tips were placed in a microcentrifuge tube containing $500 \mu$ of enzyme solution (1\% Cellulase Onozuka-RS (Yakult Honsha) and $0.5 \%$ Pectolyase Y-23 (Kikkoman), $\mathrm{pH} 4.2$ ) and incubated at $37^{\circ} \mathrm{C}$ for $1 \mathrm{~h}$. They were washed three times with distilled water. Ten to $20 \mu$ of the fixative was dropped onto root-tip and air-dried.

PCR amplification of $5 S$ and $18 S$ ribosomal DNA - Total genomic DNA was extracted according to the method of SHAW (1988) from young growing leaves of $A$. annua. PCR amplification of $5 \mathrm{~S}$ and $18 \mathrm{~S} \mathrm{rDNA}$ followed the procedure of HiZUME (1993) and SogIN (1990), respectively. The sequences of the primers were as follows: 5'-CGGTGCATTAATGCTGGTAT-3' and 5'-CCATCAGAACTCCGCAGTTA-3' for the repeating units in 5S rRNA gene clusters, and 5'-AACCTGGTTGATCCTGCCAGT-3' and 5'-TGATCCTTCTGCAGGTTCACCTAC-3' for the 18S rRNA coding regions. PCR reaction mixture (total $50 \mu \mathrm{l}$ ) contained $60 \mathrm{ng}$ of template DNA, 200 pmol of each primer, $0.1 \mathrm{mM}$ of each dNTP, 10 $\mathrm{mM}$ Tris-HCl pH 8.3, $50 \mathrm{mM} \mathrm{KCl}, 1.5 \mathrm{mM}$ $\mathrm{MgCl}_{2}$, and 1 unit of Taq polymerase (TOYOBO). Amplification was performed in a T1 Thermocycler (Biometra) programmed for one cycle of 4 min at $94^{\circ} \mathrm{C}, 30$ cycles of $30 \mathrm{sec}$ at $94^{\circ} \mathrm{C}$, $30 \mathrm{sec}$ at $60^{\circ} \mathrm{C}, 60 \mathrm{sec}$ at $72^{\circ} \mathrm{C}$, and 1 cycle of $5 \mathrm{~min}$ at $72^{\circ} \mathrm{C}$.

Fluorescence in situ bybridization (FISH) - The $5 \mathrm{~S}$ and $18 \mathrm{~S}$ rDNA probes amplified by PCR were labeled by means of random primer DNA labeling with digoxgenin-dUTP (Takara) and nick translation with biotin-14-dATP (invitorogen), respectively, following the supplier's instructions. Labeled DNA probes were denatured at $95^{\circ} \mathrm{C}$ for 10 min. Hybridization mixtures contained $50 \%$ formamide, $10 \%$ dextran sulfate and each probe at a concentration of $4 \mathrm{ng} / \mu \mathrm{l}$ in $2 \mathrm{xSSC} .25 \mu \mathrm{l}$ of hybridization mixture was put on a chromosomal preparation and covered with a cover slip and sealed with rubber gum. The slides were denatured at $80^{\circ} \mathrm{C}$ for $3 \mathrm{~min}$ on a hot plate and then incubated overnight at $37^{\circ} \mathrm{C}$ in a humid chamber. After overnight incubation, coverslips were floated off in $2 \mathrm{x}$ SSC and slides were rinsed in $2 \mathrm{x}$ SSC at $42^{\circ} \mathrm{C}$ for $10 \mathrm{~min}, 0.2 \times \mathrm{SSC}$ at $42^{\circ} \mathrm{C}$ for 10

Table 1 - Six taxa of Artemisia in Eurasia studied.

\begin{tabular}{|c|c|c|c|c|}
\hline \multirow[b]{2}{*}{ Taxon } & \multirow[b]{2}{*}{ Location } & \multicolumn{2}{|c|}{ Chromosome numbers } & \multirow[b]{2}{*}{ Reference } \\
\hline & & $\begin{array}{l}\text { Present } \\
\text { count }(2 \mathrm{n})\end{array}$ & $\begin{array}{l}\text { Previous } \\
\text { count }(2 \mathrm{n})\end{array}$ & \\
\hline \multicolumn{5}{|c|}{ Sect. Dracunculus } \\
\hline A. capillaris & $\begin{array}{l}\text { Japan: Amakusa-city, Kumamoto Pref. } \\
\text { Japan: Yamaguchi Pref. }\end{array}$ & 18 & $16,18,27$ & $\begin{array}{l}\text { Mendelak and Schweizer, 1986; Qiao et } \\
\text { al., 1990: Kawano et al., } 1995\end{array}$ \\
\hline \multirow[t]{3}{*}{ A. japonica } & Japan: Ooita-gun, Ooita Pref. & 36 & \multirow{3}{*}{18,36} & Volkova and Boyko, 1985; Volkova and \\
\hline & Japan: Minamiaso-gun, Kumamoto Pref. & 36 & & Boyko, 1986; Nishikawa, 1984; Hoshi \\
\hline & Russia: Vladivostok & 36 & & et al. 2003 \\
\hline \multicolumn{5}{|l|}{ Sect. Artemisia } \\
\hline A. annua & Japan: Nagasaki Pref. & 18 & 18 & Volkova and Boyko, 1986 \\
\hline \multirow[t]{3}{*}{ A. stolonifera } & Japan: Ooita-gun, Ooita Pref. & 36 & \multirow{3}{*}{36} & \multirow{3}{*}{$\begin{array}{l}\text { Volkova and Boyko, 1985; Hoshi et al. } \\
2003\end{array}$} \\
\hline & Japan: Minamiaso-gun, Kumamoto Pref. & 36 & & \\
\hline & Russia: Vladivostok & 36 & & \\
\hline
\end{tabular}


min, and $2 \times \mathrm{SSC} / 0.2 \%$ Tween 20 at room temperature for $10 \mathrm{~min}$ twice. Slides were blocked with $5 \%(\mathrm{w} / \mathrm{v})$ bovine serum albumen in $2 \mathrm{xSSC} /$ $0.2 \%$ Tween 20 for $10 \mathrm{~min}$ at room temperature. Signal was detected with $100 \mu \mathrm{l}$ of $5 \mu \mathrm{g} / \mathrm{ml}$ anti-digoxigenin-rhodamine (Roche) and $2 \mu \mathrm{g} / \mathrm{ml}$ avidin-FITC (Roche) in $2 \times$ SSC in each slide for $1 \mathrm{~h}$ at $37^{\circ} \mathrm{C}$ in a humid chamber. Slides were washed in $2 \times \mathrm{SSC} / 0.2 \%$ Tween 20 for 10 min twice, $2 \mathrm{x}$ SSC at room temperature. The slides were then mounted in Vectashield Mounting Medium (Vector Lab.) containing $500 \mathrm{ng} / \mathrm{ml}$ of 4',6-diamidino2-phenylinodole (DAPI).

\section{RESULTS}

Results showed that the basic chromosome number of all taxa was $\mathrm{x}=9$ (Table 1$)$. Two species are diploid $(2 n=18)$ and the two remaining were tetraploid $(2 n=36)$. These chromosome numbers were confirmed previous reports (Table 1). Chromosomes were numbered in decreasing order of length.

Figure 1 showed the results of FISH of the taxa studied. FISH with biotin labeled $18 \mathrm{~S}$ rDNA (detected with avidin-FITC) and digoxigenin labeled $5 \mathrm{~S}$ rDNA (detected with anti-DIG-rhodamine) revealed chromosome specific signal patterns. In all four Artemisia species studied, 5S and $18 \mathrm{~S} \mathrm{rDNA}$ were located in the terminal position (Fig. 1). Moreover, all $18 \mathrm{~S}$ rDNA sites are the same number and collocated with $5 \mathrm{~S} \mathrm{rDNA}$ ( Table 2, Fig. 1C, F, I and L). Intraspecific rDNAs variations was not observed (Table 2 ).

Diploid $A$. capillaris had nine rDNA sites on the median centromeric chromosomes, and seven of them were major and the remaining two were minor (Table2, Fig. 1A, B and C). Two of the hy- bridization signals were minor, each at end of short arms of chromosome 2 and 3. Two major sites were located at the terminal positions of the long arms of chromosome 13 and 14. The other five were located on the short arms of chromosome $1,9,10,11$, and 12 .

Eight $\mathrm{rDNA}$ signals were observed in the chromosomes of $A$. japonica. Six sites are located at the end of short arms of median centromeric chromosome 7, 8, 15, 16, 28 and 29, and the other two signals are at the end of short arms of submedian centromeric chromosome 22 and 23 (Table 2, Fig. 1D, E and F).

In $A$. annua, four sites were found in the chromosomes (Table 2, Fig. 1G, H and I). Two sites were located at the end of short arms of submedian centromeric chromosome 14 and 15, and the other two ones were at the end of short arm subterminal centromeric chromosome 11 and 12 .

Four rDNA signals were observed on the chromosomes of $A$. stolonifera (Table 2, Fig. J, K and L). Two sites were located at the end of short arms of submedian centromeric chromosome 31 and 32 , and the other two ones were at the end of short arms of chromosome 35, 36.

\section{DISCUSSION}

Several investigations have reported the chromosome number, and karyotypes have been applied to identify intra- and interspecific variation and to evaluate the phylogenetic relationships among several species of the genus Artemisia (MASUMORI 1961; ARANO 1962; 1963; 1964; 1965; 1970; Kawatani and Ohno 1964). However, the inter- and intraspecific chromosome is difficult to distinguish by their length and centromere position because of similar chromosome size, and

Table 2 - Number of $18 \mathrm{~S}$ and $5 \mathrm{~S}$ rDNA sites.

\begin{tabular}{|c|c|c|c|c|c|c|c|c|c|}
\hline \multirow{2}{*}{ Taxon } & \multirow{2}{*}{ Location } & \multirow{2}{*}{$2 n$} & \multirow{2}{*}{$\begin{array}{l}\text { Ploidy } \\
\text { level }\end{array}$} & \multicolumn{2}{|c|}{$18 \mathrm{~S}$ rDNA } & \multicolumn{2}{|c|}{$5 \mathrm{~S}$ rDNA } & \multicolumn{2}{|c|}{ Collocated } \\
\hline & & & & No. & $\%$ & No. & $\%$ & No. & $\%$ \\
\hline \multirow{3}{*}{$\begin{array}{c}\text { Sect. Dracunculus } \\
\text { A. capillaris }\end{array}$} & & & & & & & & & \\
\hline & Japan: Amakusa-city, Kumamoto Pref. & 18 & $2 \mathrm{x}$ & 9 & 50,0 & 9 & 50,0 & 9 & 50,0 \\
\hline & Japan: Yamaguchi Pref. & 18 & $2 \mathrm{x}$ & 9 & 50,0 & 9 & 50,0 & 9 & 50,0 \\
\hline \multirow[t]{3}{*}{ A. japonica } & Japan: Ooita-gun, Ooita Pref. & 36 & $4 x$ & 8 & 22,2 & 8 & 22,2 & 8 & 22,2 \\
\hline & Japan: Minamiaso-gun, Kumamoto Pref. & 36 & $4 \mathrm{x}$ & 8 & 22,2 & 8 & 22,2 & 8 & 22,2 \\
\hline & Russia: Vladivostok & 36 & $4 \mathrm{x}$ & 8 & 22,2 & 8 & 22,2 & 8 & 22,2 \\
\hline \multicolumn{10}{|l|}{ Sect. Artemisia } \\
\hline A. апnиa & Japan: Nagasaki Pref. & 18 & $2 \mathrm{x}$ & 4 & 22,2 & 4 & 22,2 & 4 & 22,2 \\
\hline \multirow[t]{3}{*}{ A. stolonifera } & Japan: Ooita-gun, Ooita Pref. & 36 & $4 \mathrm{x}$ & 4 & 11,1 & 4 & 11,1 & 4 & 11,1 \\
\hline & Japan: Minamiaso-gun, Kumamoto Pref. & 36 & $4 \mathrm{x}$ & 4 & 11,1 & 4 & 11,1 & 4 & 11,1 \\
\hline & Russia: Vladivostok & 36 & $4 \mathrm{x}$ & 4 & 11,1 & 4 & 11,1 & 4 & 11,1 \\
\hline
\end{tabular}




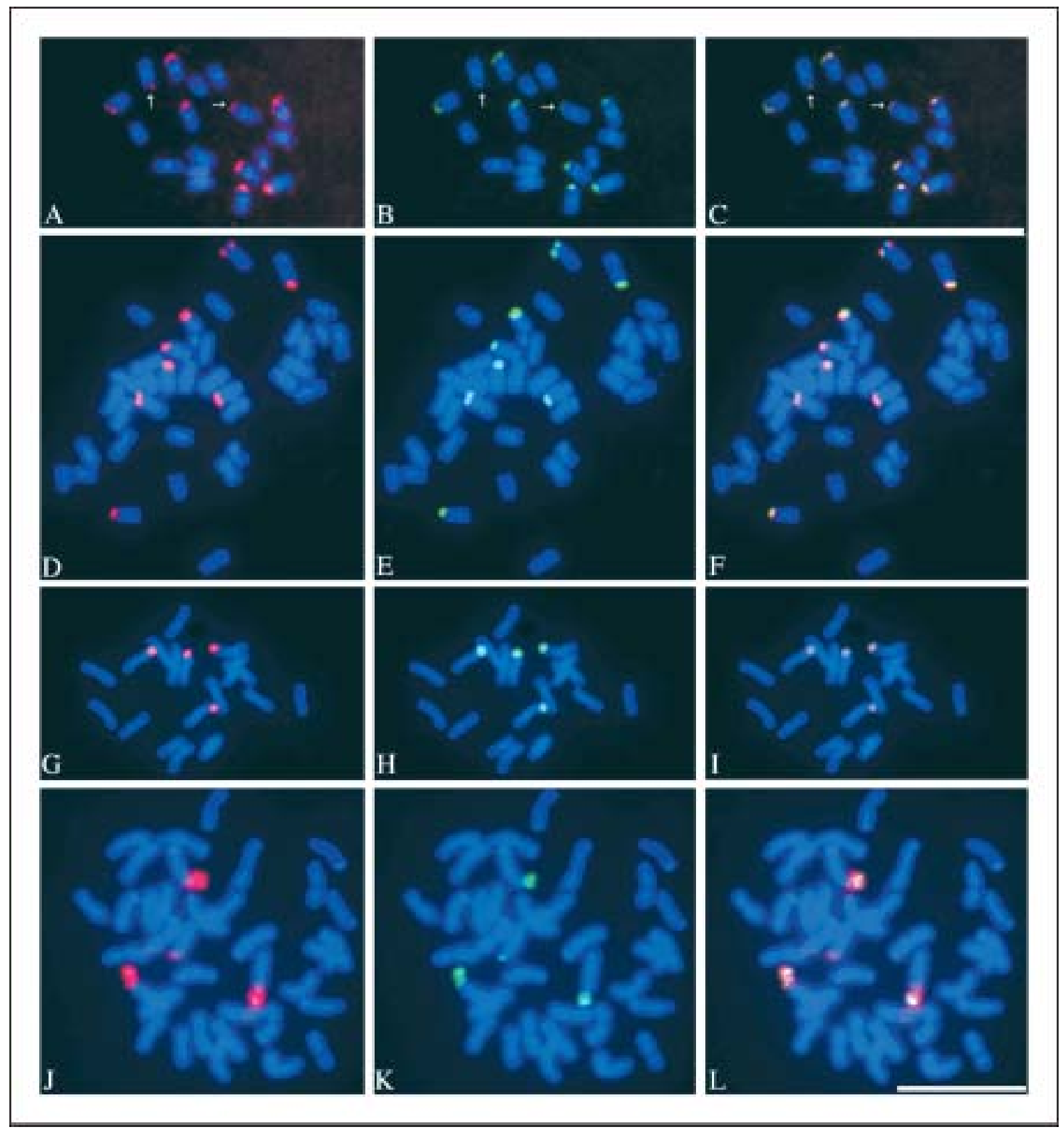

Fig. 1 - Somatic metaphase chromosomes of Artemisia capillaris (A, B and C), A. japonica (D, E and F), A. annua $(\mathrm{G}, \mathrm{H}$ and $\mathrm{I})$ and $A$. stolonifera $(\mathrm{J}, \mathrm{K}$ and $\mathrm{L})$. Localization of $5 \mathrm{~S} \mathrm{rDNA}$ in red when digoxigenin-labelled $(\mathrm{A}, \mathrm{D}, \mathrm{G}$ and $\mathrm{J}), 18 \mathrm{~S}$ rDNA in green when biotin-labelled (B, E, H and K), and simultaneous detection of $5 \mathrm{~S}$ and $18 \mathrm{~S} \mathrm{rDNA}$ (C, F, I and L). Chromosomes were counter stained with DAPI. Arrows indicate minor rDNA loci. Scale bar represents 10 $\mu \mathrm{m}$ for A to L.

identification by karyotypes is sometime unreliable (Hoshi et al. 2003).

Our FISH results showed that all four Artemisia species, $5 \mathrm{~S}$ and $18 \mathrm{~S}$ rDNA were located in the terminal position (Fig. 1). Moreover, all 18S rDNA sites were the same number and collocated with $5 \mathrm{~S}$ rDNA (Table 2, Fig. 1). Intraspecific rDNAs variations were not observed (Table 2 ). In higher eukaryotes, generally $5 \mathrm{~S}$ ribosomal DNA was unlinked to the $18 \mathrm{~S}$ to $25 \mathrm{~S}$ ribosomal DNA (ANSARI et al. 1999). In Asteraceae, the independently distribution of $5 \mathrm{~S}$ and $18 \mathrm{~S}$ rDNA loci on chromosomes had been observed in several species and its relatives (MAтовA et al. 2001; 2005; RuAs et al. 2005). Recently, Torrell et al. (2003) had reported the number and loci of $18 \mathrm{~S}$ rDNA in 
some Artemisia species, and 5S rDNA sites were the same or a lower number and collocated with $18 \mathrm{~S}$ rDNA. The collocation of the $5 \mathrm{~S}$ and $18 \mathrm{~S}$ rDNA might be a common feature of chromosome evolution in the genus Artemisia.

Our FISH results showed that there were nine, eight, four and four rDNA sites on the chromosomes of $A$. capillaris, $A$. japonica, $A$. annua and A. stolonifera respectively. In A. capillaris, nine hybridization sites were observed, and seven of them were major and the remaining two were minor (Fig. 1A, B and C). Fluorescence in situ hybridization was not a fully quantitative technique, but the intensity of signals provided approximate information concerning the copy number of gene (Appels et al. 1980; Maluszynska and HeslopHARRISON 1991). The existence of two minor rDNA loci could be presumed that the translocation of rDNA from one chromosome bearing rDNA loci to another chromosome. A similar phenomenon was reported in other species (Gu and XiAo 2003; Zhang and SANg 1999; Hanson et al. 1996), and especially the telomeric location of rDNA loci was likely to cause this phenomenon (Zhang and Sang 1999; Hanson et al. 1996). Perhaps, the minor sites of the chromosome 2 and 3 in A. capillaris were considered that translocation occurs from chromosome 2 to chromosome 3.

In some genera, the number of rDNA loci correlate with the process of polyploidization (CALDERINI et al. 1996). Polyploidy, up to $12 \mathrm{x}(2 n=$ 108), have been recognized as common phenomenon in the genus Artemisia (KaWATANI and Ohno 1964; Sharma and Sarkar 1968; Bolkhovskikh et al. 1969; Rousi 1969; BAKshi and Kaul 1984; Volkova and Boyko 1985; Malakhova 1990; McArthur and Sanderson 1999; Hoshi et al. 2003). Nine and four rDNAs sites were distributed in the chromosomes of diploid $A$. capillaris and $A$. annua respectively (Fig. $1 \mathrm{C}$ and I). On the chromosomes of tetraploid $A$. japonica and $A$. stolonifera, there were eight and four $\mathrm{rDNAs}$ sites respectively. The low loci numbers of rDNA site found in tetraploid $A$. stolonifera seem to contradict the hypothesis of the polyploidization. On the contrary, the highest numbers of rDNA sites found in diploid species $A$. capillaris (Fig. 1C). Thus, the results of this study indicated that the number of rDNA sites did not reflect the polyploid complex of the genus $A r$ temisia.

According to Watson et al. (2002), the internal transcribed spacers (ITS) of nuclear ribosomal DNA phylogeny suggested an early divergence of subg. Dracunculus from the remaining Artemisia subgenera. In diploid species, $A$. capillaris (sect. Dracunculus) has nine rDNA sites while $A$. annua (sect. Artemisia) has four rDNA sites. Possible explanation for this phenomenon is loss of some rDNA or fusion with other rDNA sites in the evolutionary process (Thomas et al. 1997; SNOwdon et al. 1997). In either event, there has been decrease in number of rDNA sites during evolutionary process of the genus Artemisia.

In section Dracunculus have eight and nine rDNA sites while section Artemisia has four rDNA sites. Despite the polyploidy was observed, the number of rDNA sites were relatively constant within the section Dracunculus and Artemisia respectively. After polyploidization, elimination of rDNA might be occured. For example, it has been known that the rDNA sites were eliminated from additional genome (CALDERINI et al. 1996; THOMAS et al. 1997). Thus, it seems that the number of rDNA loci did rely on the polyploidization, and the number was kept at the section level. In view of this feature, we proposed that there were distinct differentiation process of rDNA between sect. Dracunculus and sect. Artemisia.

In this study, we demonstrated that the number and loci of $5 \mathrm{~S}$ and $18 \mathrm{~S}$ rDNA were associated with the evolutionary process of the genus Artemisia. ITS data indicated that some "Absinthium" species had associated or been embedded within "Artemisia" (TORRell et al. 1999; WATSON et al. 2002). Further research will be needed to obtain a more obvious view of the relationships among sect. Artemisia, sect. Dracunculus and sect. Absinthium.

Acknowledgements - This study was financially supported by the Grant-in-Aid for the Scientific Program A (1) (No. 14255014; Representative: K. Kondo) of Japanese Ministry of Education, Culture, Sports, Sciences and Technology.

\section{REFERENCES}

Ali H.B.M., Meister A. and Schubert I., $2000-$ DNA content, rDNA loci and DAPI bands reflect the phylogenetic distance between Lathyrus species. Genome, 43: 1027-1032.

Anamthawat-Jónsson K. and BöDvarsdóttir S.K., 2001 - Genomic and genetic relationships among species of Leymus (Poaceae: Triticeae) inferred from 18S-26S ribosomal genes. Amer. J. Bot., 88: 553-559.

Ansari H.A., Ellison N.W., Reader M.S., Badaeva E.D., Friebe B., Miller T.E. and Williams W.M., 1999 - Molecular cytogenetic organizations of $5 S$ and 18S-26S rDNA loci in White Clover (Trifolium 
repens $L$.$) and related species. Amer. J. Bot., 83: 199-$ 206.

Appels R., W. L. Gerlach, E. S. Dennis, Swift H. and Peacock W. J., 1980 - Molecular and chromosomal organization of DNA sequences coding for the ribosomal RNAs in cereals. Chromosoma, 78: 293311.

Arano H., 1962 - Cytological studies on subfam. Carduoideae of Japanese Compositae (VI). Karyotype analysis in the gensu Artemisia. Bot. Mag. Tokyo, 75: 356-367. (in Japanese).

Arano H, 1963 - Cytological studies in Subfamily Carduoideae (Compositae) of Japan XIV. The karyotype analysis on Genus Artemisia (3). Bot. Mag. Tokyo, 76: 459-465.

Arano H., 1964 - Cytotaxonomic studies in Subfam. Carduoideae of Japanese Compositae XI. The karyotype analysis in some species of Artemisia. La Kromosomo, 57-59: 1883-1888. (in Japanese)

Arano H., 1965 - The karyotypes and the speciations in subfamily Carduoideae (Compositae) of Japan, XVIII. Jap. Journ. Bot., 19: 31-67.

Arano H., 1970 - The cytological studies in subfamily Carduoidea of Japanese Compositae. XXIV. The chromosome numbers and the karyotypes in some species of Genus Artemisia. Bull. Saitama Univ., 19: $35-45$.

Bakshi S. K. and Kaul M. K., 1984 - A new basic number of Artemisia falconeri Clarke. Chromosome Inf. Ser., 36: 9-11.

Bolkhovskikh Z., Grif V., Matvejeva V. and ZAKharyeva O., 1969 - Chromosome numbers of flowering plants. Scientific Press, Leningrad.

Bremer K. and Humphries C. J., 1993 - Generic monograph of the Asteraceae-Anthemideae. Bull. Br. Mus. (Nat. Hist.) Bot., 23: 71-171.

Calderini O., Pupilli F., Cluster P.D., Mariani A. and Arcioni S., 1996 - Cytological studies of the nucleolus organizing regions in the Medicago complex: sativa-coerulea-falcata. Genome, 39: 914-920.

Gu Z. and XIAo H., 2003 - Physical mapping of the 18S-26S rDNA by fluorescent in situ bybridization (FISH) in Camellia reticulata polyploidy complex (Theaceae). Plant Sci., 164:279-285.

Hasterok R., Jenkins G., Langdon T., Jones R.N. and Maluszynska J., 2001 - Ribosomal DNA is an effective marker of Brassica chromosomes. Theor. Appl. Genet., 103: 486-490.

Hanson R. E., Islam-Faridi M.N., Percival E.A., Crane C.F., Ji Y., Mcknight T.D., Stelly D.M. and PRICE H.J., 1996 - Distribution of $5 S$ and $185-$ $28 S$ rDNA loci in a tetraploid cotton (Gossypium birsutum L.) and its putative diploid ancestors. Chromosoma, 105: 55-61.

Hizume M., 1993 - Chromosomal localization of $5 \mathrm{~S}$ rRNA genes in Vicia fava and Crepis capillaris. Cytologia, 58: 417-421.

Hoshi Y., Kondo K., Korobkov K.K., Tatarenko I.V., Kulikov P.V., Verkholat V.P., Gontcharov A., Ogura H., Funamoto T., Kokubugata G., Suzuki R. and Mатова H., 2003 - Cytogical study in the genus Artemisia L. (Asteraceae) from Russia. Chrom. Sci., 7: 83-89.

Kawatani T. and Ohno T., 1964 - Chromosome numbers in Artemisia. Bull. Natl. Inst. Hyg. Sci. (Tokyo), 82: 183-193. (in Japanese)

Kreitschitz A. and VallÉs J., 2003 - New or rare data on chromosome numbers in several taxa of the genus Artemisia (Asteraceae) in Poland. Folia Geobotanica, 38: 333-343.

Leitch I.J. and Heslop-Harrison J.S. 1993 - Physical mapping of the 18S-5.8S-26S rRNA genes in barley by in situ bybridization. Genome, 35: 1013-1018.

Li D. and Zhang X., 2002 - Physical Localization of the 18S-5.8S-26S rDNA and Sequence Analysis of ITS Regions in Thinopyrum ponticum (Poaceae: Triticeae): Implications for Concerted Evolution. Amer. J. Bot., 90: 445-452.

Ling Y.R., 1991a — The Old World Seriphidium (Compositae). Bull. Bot. Lab. N.-East. For. Inst., 11: 1-40.

Ling Y.R., 1991b - The Old World Seripbidium (Compositae). Bull. Bot. Lab. N.-East. For. Inst., 12: 1-108.

Mabberly D.J., 1990 - A portable dictionary of the bigher plants. The plant-book. Cambridge University Press, Cambridge, U.K.

Malakhova L.A., 1990 - Kariologocheskij analiz prirodnykh populjacij redkich I ischezajushchikh rastenij na juge Tomskoj Oblasti. Bjulleten Glavnogo Botaniceskogo Sada, 155: 60-66.

Maluszynska J., and Heslop-Harrison J.S., 1991 Localization of tandemly repeated DNA sequences in Arabidopsis thaliana. Plant J., 1: 159-166.

Masumori S., 1961 - Cytological studies on Artemisia I. Karyotypes of five diploid species. Bull. Fac. Educ., Yamaguchi Univ., 11 (Pt. 2): 43-56.

Matoba H., Uchiyama H. and Koyama T., 2001 Physical mapping of $5 S$ and $18 \mathrm{~S}$ rDNA in lettuce, Lactuca sativa L. (Asteraceae). Chrom. Sci., 5: 73-77.

Matoba H., Soejima A., Hoshi Y., and Kondo K., 2005 - Molecular cytogenetic organization of $5 \mathrm{~S}$ and $18 S$ rDNA loci in Aster ageratoides var. ageratoides, A. iinumae (= Kalimeris pinnatifida) and A. microcephalus var. ovatus in Japan. Cytologia, 70: 323 330.

Matsuura H. and Suto T., 1935 - Contributions to the idiogram study in Phanerogamous Plants I. J. Fac. Sci., Hokkaido Univ., Ser., 5: 33-75.

McArthur E.D., 1978 - Sagebrush systematics and evolution. In Sageburush ecosystem symposium, pp. 14-22. Utah. State. University, Logan, Utah.

McArthur E.D. and Sanderson C.S. 1999 - Cytogeography and chromosome evolution of subgenus Tridentatae of Artemisia (Asteraceae). Amer. J. Bot., 86: 1754-1775.

Navrátilová A., Neumann P. and Macas J., 2003 Karyotype analysis of four Vicia species using in situ bybridization with repetitive sequences. Ann. Bot., 91: 921-926.

Soltis P. S. and Soltis D. E., 2000 - The role of genetic and genomic attributes in the success of polyploids. PNAS., 97: 7051-7057. 
Raina S.N., Mukai Y., Kawaguchi K., Goel S. and JaIn A., 2001 - Physical mapping of 18-5.8-26S and $5 S$ ribosomal RNA gene families in three important vetches (Vicia species) and their allied taxa consistuting three species complexes. Theor. Appl. Genet., 103: 839-845.

Ran Y., Hammett R.W. and Murray B.G., $2001-$ Phylogenetic analysis and karyotype evolution in the Genus Clivia (Amaryllidaceae). Ann. Bot., 87: 823830.

Rousi A., 1969 - Cytogenetic comparison between two kinds of cultivated tarragon (Artemisia dracunculus L.). Hereditas, 62: 193-213.

Ruas C.F., Vanzela A.L.L., Santos M.O., Fregonezi J.N., Ruas P.M., Matzenbacher N.I., and AguiarPereCin M.L.R., 2005 - Chromosomal organization and phylogenetic relationshipas in Hypochaeris species (Asteraceae) from Brazil. Genetics and Molecular Biology, 28: 129-139.

SAKAI K., 1935 - Studies on the chromosome number in alpine plants. II. Jap. J. Genet., 11: 68-73. (in Japanese)

Sharma A. and SARKar A.K., 1968 - Chromosome number reports of plants. Research Bulletin (University of Calcutta, India), 2: 38-48.

Shaw C.H. (ed.), 1988 - Plant Molecular Biology. A Practical Approach. Oxford Univ. Press, Oxford.

Shimotomai N., 1946 - The polyploidy in the genus Artemisia. Jap. J. Genet., 21: 56. (in Japanese)

Singh R.J., Kim H.H. and Hymowitz T., 2001 - Distribution of $r D N A$ loci in the genus Glycine Willd. Theor. Appl. Genet., 103: 212-218.

SNowdon R.J., KöHLER W. and KöHLER A., 1997 Chromosomal localization and characterization of $r D N A$ loci in the Brassica $A$ and $C$ genomes. Genome, 40: 582-587.

SogIN M.L., 1990 - Amplification of ribosomal RNA genes for molecular evolution studies. In PCR Protocols. A Guide to Methods and Applications (eds. Innis, M. A., Gelfand, D. H., Sninsky, J. J. and White, T. J.), pp. 307-322, Academic Press, Inc.

StebBins G.L., 1971 - Chromosomal evolution in bigher plants. Arnold, London.
SuZUKa O., 1950 - Chromosome numbers in the genus Artemisia. Jap. J. Genet., 25: 17-18. (in Japanese)

Suzuka O., 1952 - Chromosome numbers in Artemisia I. Rep. Kihara Inst. Biol. Res., 5: 68-77. (in Japanese)

Thomas H.M., Harper J.A., Meredith M.R., Morgan W.G. and KING I.P., 1997 - Physical mapping of ribosomal DNA sites in Festuca arundinacea and related species by in situ bybridization. Menome, 40: 406-410.

Torrell M., Garcia-Jacas N., Susanna A. and Vallés J., 1999 - Phylogeny in Artemisia (Asteraceae, Anthemideae) inferred from nuclear ribosomal DNA (ITS) sequences. Taxon, 48: 721-736.

Torrell M. and Vallés J., 2001 - Genome size in 21 Artemisia L. species (Asteraceae, Anthemideae): Systematic, evolutionary, and ecological implications. Genome, 44: 231-238.

Torrell M., Cerbah M., Siljak-Yakovlev S. and VALLÉs J., 2003 - Molecular cytogenetics of the genus Artemisia (Asteraceae, Anthemideae): fluorochrome banding and fluorescence in situ bybridization. I. Subgenus Seriphidium and related taxa. Plant Syst. Evol., 239: 141-153.

Vallés J. and Siljak-Yakovlev S., 1997 - Cytogenetic studies in the genus Artemisia L. (Asteraceae): fluorochrome-banded karyotypes of five-taxa, including the lberian endemic species Artemisia barrelieri Besser. Can. J. Bot., 75: 595-606.

Volkova S.A. and Вочко E.V., 1985 - Chromosome numbers in some species of the family Asteraceae from the southernpart of the Soviet Far East. Botaniceskjij Zurnal SSSR, 70: 1000-1001.

Watson L.E., Bates P.L., Evans T.M., Unwin M.M. and EsTEs J.R., 2002 - Molecular phylogeny of Subtribe Artemisiinae (Asteraceae), including Artemisia and its allied and segregate genera. BMC Evolutionary Biology, 2: 17 (12pp).

Zhang D. and SANG T., 1999 - Physical mapping of ribosomal RNA genes in peonies (Paeonia, Paeoniaceae) by fluorescent in situ bybridization: implication for phylogen and concerted evolution. Amer. J. Bot., 86: 735-740. 